This PDF is a selection from an out-of-print volume from the National Bureau of Economic Research

Volume Title: The Frontiers of Economic Knowledge

Volume Author/Editor: Arthur F. Burns

Volume Publisher: Princeton University Press

Volume ISBN: 0-87014-056-6

Volume URL: http://www.nber.org/books/burn54-1

Publication Date: 1954

Chapter Title: Stepping Stones towards the Future

Chapter Author: Arthur F. Burns

Chapter URL: http://www.nber.org/chapters/c0384

Chapter pages in book: (p. 26 - 45) 


\section{Stepping Stones towards the Future}

\section{Forecasting as a Goal of Researgh}

The forecasting of economic affairs has fascinated successive generations. Once economists began to think of 'crises' as a phase of a recurring movement, explorations of periodicity in business fluctuations followed naturally. Imaginative men reasoned that since business activity was wavelike, the time span of the waves might well be uniform, and in that event it should be possible to predict the coming of booms and depressions just as confidently as the hour of sunrise or sunset. In 1829 an American writer noted the opinion "entertained by many that every fourteen years or thereabouts, there is a sort of revolution in property-that real estate, especially, undergoes a speculative rise and fall, and that consequently wealth becomes transferred from one individual to another, by the mere operation of time." In $1844 \mathrm{~J}$. B. Turner, another American, declared that "revulsions in commerce have become a sort of . . . epidemic . . . whose periods and returns can be safely affirmed by all, while the shrewd financier is tolerably aware of their precise times." 1 When Jevons published his famous papers on crises and sunspots, a considerable English literature already existed on the periodic hypothesis, the most interesting of the early writers being Hyde Clark, who a century ago speculated on the existence of two economic cycles-one decennial, the other a full Kondratieff wave of fifty-four years.

With the increasing application of mathematical methods to economic data, hypotheses of periodic fluctuations proliferated in later years. Periodicities of forty months, seven years, eight years, ten years, and many others were repeatedly suggested. The failure of the simple periodic hypothesis to stand up under close factual scrutiny led to refinements. For example, Samuel Benner allowed cycles to vary in length, but insisted that they come in sets that are themselves repeated. In 1878 , the year in which Jevons first announced his sunspot theory to the English public, Benner had the first opportunity to see that his own periodic scheme, which for a while worked marvelously and brought him great renown, could yield false as well as true prophecies of the price of iron. Nevertheless, the line of thinking followed by Benner appealed

Reprinted from Twenty-seventh Annual Report of the National Bureau of Economic Research (March 1947), pp. 3-27.

1 This and the preceding quotation are from Harry E. Miller, Banking Theories in the United States before 1860 (Harvard University Press, 1927), pp, 192, 193. 
to some economists, while others speculated, as had Hyde Clark before them, on the existence of several or many cycles running a simultaneous course. As the scope of economic statistics expanded and the irregularity of successive business cycles impressed itself on observers, interest shifted increasingly to the study of sequences -that is, to a search for repetitive leads or lags among different activities. More recently still, the Keynesian consumption function, tied to estimates of private investment and the governmental deficit, has become the pillar of forecasting techniques.

Practically every forecasting device ever suggested has occasionally proved successful. But it does not appear that any method has as yet yielded, for any long period, consistently good predictions of changes in business activity. This unsatisfactory record is not peculiar to business cycle forecasting. Werner Sombart begins the last chapter of his Hochkapitalismus with these words: "The prediction of the future is always a hazardous affair. And in the sphere of economic and social history it seems to be especially dangerous. It is precisely the most gifted men who have made the most fundamental mistakes." With this warning to the reader behind him, Sombart at once plunges into an account of what economic organization will be like in the future. He is not deterred by the experience of his great predecessors-Ricardo, Mill, Marx, Schmoller, and many others. And, of course, Sombart does merely what every one of us is always doing. If forecasts go awry, we do not stop forecasting. We merely try to profit by our own and others' mistakes, or as we commonly put it-'to learn by experience.' And there is little else that we can do. Prediction is inseparable from life. All human activity-whether within or outside the economic sphere-inevitably reflects forecasts of the future, mingled with current pressures and past commitments. The forecasts are sometimes bold, definite, and comprehensive; more often they are hesitant, amorphous, uttered instinctively-if at all. The choice before man is not whether to engage in forecasting or to abstain from it, but whether to base expectations on 'hunches' or on lessons carefully distilled from experience.

Systematic analysis of actual economic experience has been the principal objective of the National Bureau and other research organizations. Investigators affiliated with a center of economic research can draw on a large and growing body of factual data; they may count on clerical and computing assistance in developing new information; most important of all, they find colleagues working on cognate problems and possessing skills that complement their 
own. Investigators thus equipped are in a better position to crossexamine history effectively than the scholar who relies entirely on his own strength. If they use their opportunities properly, they should offer increasingly sound testimony not only on the regular and repetitive features of experience, but also on history's disconcerting habit of springing surprises. In this report I shall illustrate the contribution that the National Bureau is making to this great purpose, by commenting briefly on our recent investigations.

\section{The Structure of National Income}

For my first illustration I draw on Simon Kuznets' work on income distribution. In National Income: A Summary of Findings, published last year, Kuznets shows succinctly how our national income during the twenty years between the two world wars was divided among the factors of production, among individuals, among different industries, and among different uses. About twothirds of the nation's income accrued to employees, another sixth to proprietors; the remaining sixth was paid out as rent, interest, and dividends, in roughly similar proportions. The top 1 per cent of the income recipients enjoyed about an eighth, and the top 5 per cent about a fourth, of the nation's income. Manufacturing accounted for about a fifth of the total, mining for a fiftieth, agriculture a tenth, government an eighth. About 93 per cent of the nation's net product, which is equivalent to its income, passed into the hands of the public as consumption goods; only about 7 per cent was added to the stock of capital goods or to claims against foreign countries. Of the goods flowing to consumers the preponderant part-approximately 75 per cent-consisted of services and perishable commodities.

These remarkable data on the disposition of the net product of our economic activity substitute quantitative approximations for the vague conjectures with which earlier generations had to do their economic thinking. They fix our ideas about the order of magnitude of different branches of production, of the incomes accruing to the fortunate few and to the masses, of the goods consumed quickly and those consumed slowly, of the incomes received by workers and men of property. In these various ways, and as far as they go, the proportions I have cited delineate the structure of our economy. But how dependable are the proportions? What guide do they offer to the years ahead, once wartime dislocations have been largely overcome? The figures for individual years help to answer these questions. They show that the compensation of 
employees has been a fairly steady proportion of the nation's income. This proportion has not varied from, say, 20 per cent in one year to go per cent in another, but has moved within a comparatively narrow range, never falling below 59 or rising above 74 per cent between 1922 and $193^{8}$. Other components of national income likewise show rough stability in their order of magnitude. For example, dividends are a consistently small fraction of the national incorne, at no time exceeding 8 per cent; the share of the top 1 per cent bracket of the population is about one-eighth of the total in every year covered; the share of agriculture in no year exceeds a tenth, and the share of manufacturing stays within the limits of 15 and 23 per cent. Capital formation is notoriously unstable, but is nevertheless a consistently small element in national income: year in and year out the dominant part of our output has moved into the hands of the public, in no year has this part fallen below 88 per cent, and in some years the nation at large has even dipped into its accumulated stockpile. ${ }^{2}$

This rough stability in the relations among different parts of the national income during 1922-1938 is the more impressive because I have made no distinction between years occupying different stages of the business cycle, or even between the placid twenties and the turbulent thirties. In view of the comparatively narrow range within which the figures move, it seems reasonable to expect that once reconversion is fully accomplished, the broad divisions of our national income will not be very different from the prewar averages. For many purposes of economic analysis, this rough and confident projection of prewar averages will suffice. No student who accepts the figures as substantially accurate is likely to think otherwise, unless he expects a revolutionary change in our institutions, or is concerned with specific problems of economic organization rather than its broad and abiding features.

\section{Forecasting Business Conditions}

The projection of national income in the years ahead or even in the next twelve months poses a much more difficult problem than the projection of the proportions in which national income is divided. Past experience fails to furnish the forecaster with any rule that is at once simple, objective, and trustworthy. Business

2 Pertinent figures for individual years are given in Kuznets' National Income and Its Composition, 1919-1938 (National Bureau, 1941), Vol. I, Tables 12, 22, and in his National Product since 1869 (National Bureau, 1946), Table I-18. Data on the distribution by size are published in Kuznets' Shares of Upper Income Groups in Income and Savings (National Bureau, 1952). 
conditions not only alternate between prosperity and depression, but each cycle in business activity differs significantly from all its predecessors. Between 1885 and 1914 there was some approach to a 40-month cycle in the United States; this rough rule vanishes as we move forward or backward. The shortest business cycle of which we have a definite record lasted 17 months, the longest 101 months. Factory employment declined 5 per cent in one business cycle contraction, 42 per cent in another; the range of cyclical declines in factory payrolls runs from 5 to $6_{5}$ per cent, in pig iron production from 17 to 86 per cent, in industrial stock prices from 12 to 86 per cent. Exports parallel the movement of aggregate activity in one business cycle, move inversely in another, haphazardly in still another. Bank deposits rise during some business cycle contractions, decline in others. The like is true of bank loans and investments. Trading in corporate shares recovered 19 months earlier than general business activity in one instance, slumped 23 months earlier in another instance, recovered 7 months later in a third, and slumped 4 months later in a fourth. At the peak of 1929 wholesale commodity prices reached a maximum 10 months before industrial production; at the trough of $193^{8}$ their minimum point came 14 months later.

At first glance it may seem impossible to extract any order whatever from such highly variable phenomena. Yet the studies by Wesley Mitchell and his collaborators demonstrate that although business cycles are decidedly less regular than theorists are prone to assume, they are far more regular than observers preoccupied with individual episodes commonly suppose. I may illustrate this broad conclusion, which I think is basic to a true perspective, by summarizing an experiment reported in Measuring Business Cycles, another of last year's publications. The experiment was performed on seven highly significant series, extending back to the 1870 's or earlier. Two series represented the production of durable goods, two the money market, two the stock market, and one the aggregate volume of transactions. When these series were examined individually, very wide differences appeared in their behavior from one business cycle to the next. The result was similar when the behavior of the seven series during one business cycle was compared with their behavior during other business cycles. But when the measures of each series were averaged for small groups of cycles, whether on a chronological or some analytic plan, the idiosyncrasies of the individual case tended to vanish. The average behavior of the same series in one group of cycles as a rule turned 
out to be very similar to its behavior in another group, the average patterns of the several series became sharply differentiated within each group, and the relations among the various series persisted with great regularity from one group of cycles to the next; in other words, a strong tendency towards repetition in the sequence of different activities at revivals and recessions, and in the direction and amplitude of their response to business cycles, came clearly to the surface.

This experiment suggests an important conclusion: namely, that although every business cycle is a unique historical episode, the characteristic features of business cycles have been substantially uniform in the long run. The experiment gives little or no support to the widely held view that depressions are becoming progressively more severe, or to the hypothesis that business cycles succeed one another in a repetitive order that generates long waves. Of course, findings based on a small group of series, however important they may be, cannot be regarded as conclusive. But the present findings have already been tested informally on numerous series; and while methodical testing is still necessary and may turn up surprises, it can be said definitely that if, as seems plausible a priori, business cycles actually have undergone secular or structural or rhythmical changes, such changes have not impressed themselves very clearly on statistical records and must be small in comparison with the rather haphazard variation of successive business cycles.

The monograph on Measuring Business Cycles foreshadows other findings that may prove significant to economists and men of affairs. I shall single out four that seem to me especially important. (1) The volume of activity at the peak of a business cycle has as a rule exceeded the level reached at the preceding peak. The outstanding exception occurred in 1937 when activity fell short of the 1929 peak; another exception apparently occurred in 1895 . (2) The amplitude of a business cycle expansion gives little or no clue to the amplitude of the following contraction. On the other hand, there is some tendency for the amplitude of a business cycle expansion to be correlated positively with the amplitude of the preceding contraction. The difference in the two relations reflects the fact that the volume of activity has been decidedly more uneven at successive troughs than at successive peaks of business cycles. (3) While there is a broad tendency for economic activities to fluctuate in unison, expansions and contractions run side by side at every stage of a business cycle. The degree to which indi- 
vidual processes resist a cyclical movement in aggregate activity depends largely on its amplitude. In a mild business cycle expansion or contraction, countercyclical movements are relatively numerous. In a vigorous cyclical phase, on the other hand, few processes run counter to the general tide. (4) During an expansion in aggregate activity the number of expanding processes tends to increase for a time, then diminish; in other words, the number of expanding processes tends to reach a maximum before the expansion in aggregate activity itself culminates. Likewise, once a business cycle contraction gets under way, it engulfs a wider and wider range of activities; but in every stage of a general contraction some processes keep expanding, and their number typically passes through a minimum before aggregate activity itself turns up again.

These broad generalizations provide some clues to the maze of irregularities in the actual course of events, and may prove helpful in anticipating changes in the direction of aggregate activity. But they also carry a warning against oversimplification of the problem of forecasting business conditions. Possessing as it does an exceptionally full record of cyclical fluctuations, the National Bureau may render a valuable service by hunting for regularities where there seems the best chance of finding them-not in the relations between pairs or small groups of time series, or within the last few years, but in the relations among numerous and varied activities over decades. Early in $193^{8}$ we published a bulletin on statistical indicators of cyclical revivals, which began by listing the attributes of an 'ideal' indicator. Not one of the hundreds of time series examined met all the specifications; but since a carefully selected group of series can be more reliable than any single series, we segregated the series that had proved most trustworthy in the past, and presented the list in the hope that it might aid men of judgment to interpret the general drift of current conditions. In view of later experience with the list, the gains in knowledge since it was drawn up, and the heavy responsibilities of government under the Employment Act of 1946, it has seemed our duty to undertake a thorough revision of the earlier study and this time investigate recessions as fully as revivals. The results of the new study are approaching completion and will be published as promptly as possible.

In the meantime our exploration of the fundamentals of business fluctuations is being pushed energetically. The first fruits of Mills' study, which is unmasking the underlying features of the cycles in prices, production, and sellers' receipts, were harvested 
last year under the title Price-Quantity Interactions in Business Cycles. Another valuable study is Mendershausen's Changes in Income Distribution during the Great Depression. Several additional publications on business cycles may be expected this year or next: Hultgren's analysis of costs, prices, and profits in the railroad industry; Moore's report on the interrelations between crop fluctuations and business cycles; Ruth Mack's analysis of the processes by which shifts in the demand for shoes are transmitted to earlier productive and distributive stages; Evans' study of the ebb and flow of business incorporations since the early days of the nineteenth century; Abramovitz' analysis of the processes whereby inventories are built up and drawn down; Mills' full evidence on the relations between the cyclical movements of prices and production; Wolman's investigation of the behavior of wage rates at recoveries and recessions; and Mitchell's progress report on what typically happens in all leading economic activities during a business cycle.

\section{Trends in Spending and Saving}

I suggested earlier that the proportions in which national income is divided can be projected more reliably than the curve of national income itself. It may be objected that the contrast rests on a simplification that for some purposes is intolerable. Surely, the trade union strategist concerned with labor's precise share in national income in the years ahead cannot rest content with a projection of prewar averages, nor can the farm specialist pondering the role of agriculture in the national economy, or the fiscal expert mapping the revenue needed to sustain the expanded sector of governmental enterprise. Men faced with problems of this nature will seek to take account of the slowly evolving changes in economic organization that are concealed by averages for the interwar period. They will want to analyze secular trends over a still longer time if possible, and give due weight to the changes wrought by the war itself. Investigators who embark on such speculations concerning future trends will find their task facilitated by Kuznets' two volumes published last year-National Income: $A$ Summary of Findings and National Product since 1869 .

The latter monograph is devoted to a statistical analysis of the growth of the American economy. In broad summary, aggregate real income in the 1920's was almost eight times as large as in the 1870 's, and per capita real income was almost three times as large. The rate of growth was uneven, but every decade up to the 1930's 
registered substantial improvement. During that decade per capita income fell appreciably below the level of the 1920's; nevertheless it was higher than in any other decade, and about two and a half times as large as in the $1870^{\prime} \mathrm{s}$. What this amazing performance has meant to the American people is suggested by Kuznets' division of total output into the part that passed into the hands of consumers and the part that was added to the nation's capital. Between 1869 and 1938 the out - ut of the American economy amounted to about $\$ 2,800$ billion in $19^{2} 9$ prices. Of this huge total, the flow of commodities and services to consumers accounted for fully go per cent, and this figure would be raised 2 points if residential buildings were classified as consumer goods. The remaining 8 per cent includes new industrial plants, business structures, public improvements, additions to inventories, and additions to claims against foreign countries.

If these figures fail to excite the reader, the reason may well be that Kuznets' findings concerning capital formation in the interwar period are now common knowledge. Before Kuznets' original results were published, most economists had extremely vague notions about the relative magnitude of capital formation, and some actually believed that a great if not dominant part of our rapidly expanding industrial power was diverted to the building of new houses, factories, roads, machinery, equipment, and other capital goods. Kuznets demonstrated that there was no foundation for this opinion even in the experience of the 1920's, and he has now extended the demonstration back to the Civil War.

It also appears from his new study that savings were a nearly constant fraction of the national income, decade after decade, before the 1930's. This result, if broadly valid, throws new light on processes of spending and saving in a progressive economy. A typical speculative analysis of the savings problem starts with the observation that the percentage of income going into savings tends to rise as family income increases, then notes that the incomes of families have risen generally and substantially over the years, and ends by inferring that savings have been a steadily rising fraction of national income. But according to Kuznets, that has not happened. Apart from possible complications on the side of business savings, the reason must be that the static tendency of the savingsincome ratio to rise as family income increases has been counteracted historically by the tendency of the 'propensity to save' to decline; that is, the average American family with a real income of any given size has tended over the decades to save a progressively 
smaller fraction of its income. Many influences have surely worked in this direction. The most important seem to have been, first, the shift of population from rural to urban areas, second, the relative decline of independent proprietors in the general scheme of entrepreneurship, third, the increasing range of commodities and services considered necessary for acceptable living standards.

The secular decline in the 'propensity to save,' so strongly suggested although not directly demonstrated by Kuznets' calculations, has an obvious bearing on the long-run prospects of the American economy. If the decline should continue, as seems not unlikely, the prospect that our economy may be able to maintain a generally high level of employment without prodigious private investment or government spending is by no means so dark as appears from some recent mathematical projections of national income, which blink the secular element in the savings-income relation.

\section{The Long-Term Economic Outlook}

But secular trends can change on short notice, and the forecaster's inescapable ordeal is to distinguish, somehow, the short-run movements that release new trends from others, no less prominent, that soon fade away. Ricardo saw the problem clearly. He warned his contemporaries at the end of the Napoleonic War not to confuse a temporary "revulsion of trade" with a "retrograde state of society," but at the same time honestly added that "it would perhaps be difficult to point out any marks by which they may be accurately distinguished."'3 That difficulty, unhappily, has not been erased by time. During the 1920's some economists thought they had escaped from it by embracing a 'law of growth,' and some today believe they can do so by embracing a 'stable consumption function.' But the signs are multiplying that, although the latter conception may prove even more fruitful than has the former, the forecasts yielded by the one can be just as misleading as those stemming from the other.

The economic catastrophe of the 1930's continues to weigh heavily in speculations about the future, but the simple fact is that no one can tell today with any great confidence whether that experience defines a new trend of stagnation or a passing historical episode. Kuznets' findings concerning the long-run trends of savings and consumption are reassuring. But once the present boom has run its course, if the volume of investment should revert to

$s$ Principles of Political Economy, ed. Gonner, p. 250. 
the level of the 1930's, may not even a substantial decline in the 'propensity to save' prove insufficient to sustain the high level of income that seems physically within our reach? The intense activity of recent times has thinned the ranks of those who accept the doctrine of secular stagnation. So too has the widespread realization that a huge backlog of replacements has accumulated in industry, that years must pass before the housing shortage is eliminated, that vast opportunities for exporting capital may soon become available, and that immeasurable investment outlets may be opened up by aviation, radar, atomic energy, and other technological wonders. Nevertheless, the spectre of secular stagnation still haunts the minds of some sensitive men as they look beyond the next five or ten years. And while their dark forebodings are based on an untested hypothesis of economic development, they cannot be dismissed outright, as some believe possible, merely by citing the investment opportunities afforded by foreign countries and by technological innovations. For, on the one hand, foreign investment on a considerable scale is impossible in an atmosphere of international distrust and, on the other hand, technological progress can go on at a rapid rate and investment still remain at an unsatisfactory level.

The experience of the thirties abundantly illustrates both of these statements, but I shall confine myself to the latter. Jacob Gould's monograph on Output and Productivity in the Electric and Gas Utilities, still another of our publications last year, shows that between 1929 and 1939 the output per unit of labor increased 92 per cent in the electric light and power industry, and 20 per cent in the manufactured gas industry. Other studies by Fabricant, Barger, and their associates show gains of 24 per cent in agriculture, 26 per cent in coal mining, 33 per cent in manufacturing, and 32 per cent in steam railroads. ${ }^{4}$ Plainly, technological progress made rapid strides on a wide industrial front. In fact, as Gould demonstrates, the reduction in unit labor requirements effected by American industry during the 1930's was not very different from the reductions achieved in preceding decades, at least since 1900. But before 1929 increasing efficiency in the use of labor was generally accompanied by a rising trend in the aggregate number of men employed, while in the following decade the ability of private enterprise to create new jobs was drastically impaired and the increase in technical power dissipated in mass unemployment.

\footnotetext{
4 See "Economic Research and the Keynesian Thinking of Our Times," Table 1, above.
} 
The causes of this extraordinary setback to progress have been extensively debated, but not thoroughly investigated. What part did the decline in the rate of growth of population play? Did a significant shift take place from capital-using to capital-saving innovations? Is there any validity in the hypothesis of an unfavorable conjuncture of economic cycles with different wave lengths? In what degree may monopolistic practices of business firms and labor unions be held responsible? What part did the policies of the New Deal play-with respect to taxation, borrowing, labor, public utilities, the security markets? Were foreign developments responsible in any significant degree for our economic plight? And if so, in what measure did we export economic trouble before we in turn imported it? Some of these questions are now being explored by Wolman in his studies of the labor market. The Conference on Research in Fiscal Policy will consider others in a new investigation of the influence of different types and levels of taxes on business enterprise. But if I am right in thinking that a fuller understanding of what happened in the 1930's may contribute vastly to the shaping of wise economic policies in the future, there is room in our program for a study which, while drawing extensively on research now in process, is devoted specifically to the problems and events of that period.

To accomplish its purpose the study should rest on a broad inductive foundation, and this must be sought in a comparative analysis of earlier periods and other countries. As the research work of the Bureau has taken shape, we have found it necessary time and again to carry measurements back into the past. But the economic experiences of foreign countries in recent years may prove no less instructive than our own economic fortunes in a remote past. And neither recent nor distant American experience can be understood apart from foreign events. The importance of these methodological principles was fully recognized at the beginning of our work on business cycles, and has not been neglected in other parts of the Bureau's program. At present our 'foreign' research includes Morgenstern's investigation of the financial relations among different countries during business cycles, Smit's study of the phenomena connected with the international gold standard during 1816-1914, Hultgren's study of transportation and Moore's of crops in relation to the business cycles of Western Europe, Maxwell's survey of the development of fiscal relations between the Dominion of Canada and its provinces, Higgins' study of British banking and finance during the war, Long's study of the labor 
force in several countries, Bry's study of wages in Germany, and Copeland's measurements of the flow of payments between the United States and the rest of the world. Wide-ranging though these studies are, they can provide only a small part of the materials needed to interpret what happened in the United States during the 1930's, to say nothing of the larger problem of America's changing role in the world economy. If we are to realize these objectives, we must give more attention to foreign economies and the links that tie us to them than we have in the past.

\section{Economic Penetration of the Service Industries}

One of the deepest trends in a country undergoing rapid industrialization is the relative shrinkage of the commodity-producing industries taken as a whole. This trend appears clearly in Kuznets' industrial breakdown of the national income in the United States, and stands out still more prominently in the longer series on the labor force. In 1870 agriculture, forestry, fishing, manufacturing, mining, and construction together accounted for $7^{6}$ per cent of the labor force; their combined percentage fell to 68 in 1900 , to 61 in 1920 , and to 48 in 1940 . If the miscellaneous category that mars statistical tables on the labor force is counted with the commodityproducing group, obviously a doubtful statistical expedient, the percentage in 1940 rises from 48 only to 55 . If transportation and public utilities are also lumped in their entirety with the commodity group, another doubtful expedient, the percentage is still only $62 .^{\circ}$ The remaining $3^{8}$ per cent of the labor force in $194^{\circ}$ was scattered in trading and financial establishments, a great variety of private services, and in government work. During the war the commodity-producing sector expanded sharply, but the services now seem to be reasserting their secular force.

These facts have not as yet been fully assimilated in our thinking. Treatises on economic theory continue to be written as if manufacturing and the extractive industries were the only ones of any consequence. With important exceptions much the same emphasis is found in journalistic writings, governmental policies, and even official statistics. But if technological progress in the commodity-producing industries continues at anything like the pace felt during the past half century, will not the service industries soon become the primary source of employment? May we expect the services to expand sufficiently to fill the 'gap' between those

\footnotetext{
5 Based on estimates by Daniel Carson in a paper presented at the National Bureau's Conference on Research in Income and Wealth, November 1946.
} 
needed in the commodity-producing industries and the total labor force? To what extent is technological progress likely in merchandising establishments, financial businesses, personal service industries, the private professions, and government work? What are the implications of the growth of the service industries for the problem of monopoly? What are the implications for the problem of business cycles? What is the cultural incidence of the changing character of the labor force? Are our institutions flexible enough to prevent a hierarchy of special privileges from being amassed by aggressive sections of the commodity-producing group?

To cope with these and related questions, factual information on the service sector of the economy is essential. But the service industries are a vast conglomerate, including activities as diverse as specialized medicine, on the one hand, and street sweeping, on the other. Neither the social significance of the penetration of the service industries, nor their capacity for further expansion, can be accurately gauged from broad aggregates. For example, the number of physicians was 157 per 100,000 persons in 1900, and only 133 in 1940 . In 1900 there were 1,980 servants per 100,000 persons, in 1940 only 1,590 . On the other hand, the number of public school teachers increased faster than population, yet not so fast as the entire class of government workers. According to Fabricant's estimates, government employees constituted 4.5 per cent of the labor force in 1900; this percentage doubled by $194^{\circ}$ and on July 1,1946 one out of every ten workers was on some governmental payroll.

These illustrative data emphasize both the importance of analyzing trends in the service industries, and the need of examining them individually. Among our recent publications is the highly original monograph on Income from Independent Professional Practice by Friedman and Kuznets. Initiated by Kuznets, who in the course of work on national income had felt keenly the lack of data on the services, this study was executed mainly by Friedman. A second publication on the service industries is last year's Occasional Paper by Stigler, which presents some very useful information on the number, incomes, and working conditions of domestic servants - a class of workers hitherto neglected by professional economists, although before the war they were as numerous as the employees of railroads, coal mines, and automobile factories combined. Other monographs now being prepared will deal in detail with education, trade, and government, as well as the service industries in their entirety. 


\section{The Changing Financial Structure}

Financial institutions rank low among the service industries as employers of labor, but they exercise great influence on the economy by their activities of lending, investing, and providing the community with means of payment. In 1900 a typical commercial bank might still have been described as performing the classical functions of deposit, discount, and note issue. At present that description can only excite historical interest. The power of note issue, barred for all practical purposes to state banks since the Civil War, is no longer exercised even by national banks. The place once occupied by short-term commercial loans in the portfolio of a commercial bank has been preempted by federal securities. Total loans and discounts of commercial banks in 1946 were considerably below the level reached in 1929, despite the great increase in production and the rise in prices. Investments in federal obligations, on the other hand, have soared in recent years. At the end of June 1946 they accounted for over 9o per cent of the investments held by commercial banks, and investments in their turn were more than three times as large as loans.

The enormous volume of securities now tucked away in the vaults of commercial banks represents largely a monetization of the federal debt. But in looking to the future, it is important to bear in mind that the recent war accentuated a trend long in the making. Government securities first became a considerable factor in commercial bank assets during World War I. In the 1920's commercial banks did not increase their holdings of federal obligations materially; however, the holdings of other securities expanded much faster than loans, and as a consequence loans diminished relative to investments. During the Great Depression loans were sharply deflated; but government obligations offset the shrinkage in other securities, and investments as a whole changed little. In 1934 investments of commercial banks outstripped loans for the first time. Banks added heavily to their federal securities between 1934 and 1939, and by the end of the latter year investments exceeded loans by 36 per cent. During the next six years both loans and investments increased, but the growth of investments was much faster. Last year investments declined appreciably, but the drop is of slight significance, since the Treasury merely used its swollen deposits in commercial banks to retire a sizable block of its securities.

The momentous changes in the functions of commercial banks since 1900 are analyzed by Jacoby and Saulnier in their monograph 
on Business Finance and Banking, which has just been published. The authors of this scholarly study focus attention on the changing relations between business concerns and commercial banks. In exploring the causes of the relative decline of 'commercial lending' since the 1920's, they analyze, first, the changes in the industrial composition of the economy to which I referred earlier in this report; next, changes in the size of business enterprises, in the types of assets held by business concerns, and in the competitive framework within which commercial banks have functioned. The study makes an important contribution to the understanding of how business, as well as banking, practices have developed in recent decades.

The provision of means of payment is the one function that commercial banks today discharge much as they did in 19oo. It is a curious fact that despite the widespread and persistent interest of economists in the supply of money, current monthly measures of the aggregate supply of means of payment have become available only in the last few years. A historical background for interpreting the new official compilations on the public's currency holdings is provided by the recently published Technical Paper by Anna Schwartz and Elma Oliver, which presents monthly estimates of currency held by the public since 1917. We hope that this statistical record may soon be supplemented by another showing, month by month, the public's holdings of deposits.

However important statistics on the supply of money may be, it is difficult to interpret them apart from measures of the turnover of money. The common impression that the supply of money fluctuates in close harmony with aggregate economic activity is not supported by a long view of history. That much seems firmly established by our investigation of business cycles, as is also the great sensitivity of the turnover of money to fluctuations in aggregate activity. In our studies of business cycles we have hitherto relied heavily on approximations of the aggregate supply of money, its average rate of use, and the aggregate volume of payments. We have been unable to differentiate sufficiently the stocks of money held or the payments made by leading groups of transactors in the economy. This gap in statistical information has been a barrier to scientific progress, but there is a prospect that Copeland's experiments in tracing the flow of money may soon improve matters. The Board of Governors of the Federal Reserve System has recognized the high importance of his undertaking and will attempt, in 
collaboration with the National Bureau, to develop statistics on the flow of money on a current basis.

In tracing money flows Copeland presents information on the debt and credit position, as well as the amounts paid and received, for each of various groups of transactors. For one category of debt, corporate bonds, the National Bureau has for some time sheltered in its files a virtual census, starting in 1900. Analysis of this extraordinary body of information was begun last year under Hickman's direction. One of the principal aims of the new project is to develop investment experience tables that may serve as a guide for evaluating securities and establishing loss reserves. Related studies of risk experience with mortgages are being conducted by Saulnier and his associates. If these investigations prosper, the fickleness of individual securities may be no obstacle in the future to tolerable forecasts of security experience in the mass.

\section{The Growth of Government}

One reason for the decline of 'the commercial loan' in bank portfolios is the expansion of government and its heavy reliance in recent years on borrowing. Indeed, the outstanding trend in the service sector of our economy has been the growth of government. The figures on employment that I cited earlier are merely important symptoms. They include regular civilian employees of government, but omit the employment afforded by private industry on account of governmental purchases. They do not even include military personnel or workers on emergency public projects. And, of course, no employment figure, however comprehensive, can give any inkling of the influence of interest on the public debt, or of payments to veterans, or of financial aid to foreign countries, to say nothing of the influence exercised by government on the economic life of the nation through nonfiscal devices.

The colossal wartime expenditures of government have now abated. Also, the pervasive controls of private industry are being lifted, and free markets reestablished. But a very large part of the nation's income continues to flow through government channels. The ratio of government expenditures (inclusive of so-called transfer payments) to the gross national product, which was 20 per cent in 1939 and rose to 52 per cent in 1944, was still about 35 per cent in 1946. A further reduction may reasonably be expected during the next few years, but the figure is likely to remain above the prewar level. However loudly the public may grumble about taxes, there is no easy escape from the fiscal problem facing the 
nation. In a careful analysis of the federal budget, now nearing completion, Crum and Kendrick have reached the conclusion that federal expenditures during the first postwar decade may well average $\$ 32$ billion per year [in 1947 prices]. If state and local outlays are added in, government expenditures may approach the $\$ 45$ billion mark.

The recent shift of the political tide in this country may check the government's part in the economy of the nation, but it seems unlikely that the reduction will be large or permanent. The size of the public debt and the obligation to veterans work strongly against curtailment of governmental activity; so too do the assumption of responsibility for a high level of employment, the growing awareness of the needs of underprivileged groups, the continuance of international rivalry and friction, the spread of collectivism abroad, and our own tradition of governmental intervention. The practical question is not whether the government need play an important part in the nation's economic life, but how that part will be played. Under the circumstances, the $\mathrm{Na}$ tional Bureau can make a useful contribution to public policy by subjecting large governmental activities to objective study. The investigations now being conducted by Crum, Seltzer, Smith, and their associates of the Conference on Research in Fiscal Policy are a step in this direction. So also is Fabricant's investigation of trends in government employment, as well as Colean's study of the influence of government on urban real estate finance.

The novel statement of federal finances devised by Copeland in the course of his experimental tracings of the flow of money is a welcome addition to our inadequate kit of tools for analyzing fiscal policies. This statement makes available for the first time a clear and comprehensive record of federal fiscal operations, and will be published promptly as a Technical Paper. The statement combines transactions of public service enterprises, credit agencies, and insurance funds with general federal operations. It shows dealings with the public, not interagency transactions; in short, it gives the sort of information needed to trace the impact of fiscal operations on the economy. If plans for developing the data on a current basis materialize, as now seems likely, economists will gain a new weapon in their struggle with 'the shape of things to come.'

\section{Forecasting and Economic Policy}

Economists are now engaged in a lively discussion of the business outlook. At no time since the 1920's have forecasters been so out- 
spoken, insistent, and self-confident. Strong in faith, they address their predictions-sometimes in ordinary prose, sometimes in esoteric symbols-not only to business executives and the stock-buying public, but also and preeminently to government itself. Today's forecasters have enormous advantages over their predecessors: keener analytic tools, longer and better statistical records, sounder analyses of past experience. These stepping stones towards the future will become firmer with time, but two serious difficulties are likely to remain in the forecaster's path: first, the imperfect tendency of history to repeat itself; second, the forecaster's own hopes and fears about the future, which tend to insinuate themselves into his predictions, no matter how elaborate their statistical or mathematical scaffolding.

The recent outburst of articulate forecasting will bear careful watching. A scientific investigator can learn nothing from the intuitive prophet, whether his forecasts prove true or false. On the other hand, the forecasters who are now devising ingenious theoretical models may contribute significantly to economic science, even if many of their forecasts prove wrong. The economist who values truth must discriminate conscientiously among false prophets, but it is also his duty to warn men of affairs that they cannot safely practice similar tolerance. At our Twenty-fifth Anniversary celebration last June, Joseph S. Davis stressed the need for wider recognition of the nature of economic forecasts. His sage remarks deserve repetition: "In economics . . really scientific predictions are usually impossible except as statements of what can be expected under a certain combination of assumptions. Such specialized predictions have their place, but they are too easily confused with outright prophecies. The assumptions underlying the forecasts, and the margin of error in them, typically deserve as much weight as the forecasts themselves, if the users and indeed the authors are not to be misled. But there is greater need of warning that certain forecasts cannot be made within a margin of error small enough to warrant serious reliance upon them. This is true of many forecasts-of crops, of food supply and demand, of labor force and unemployment, and even of population some decades ahead. Policies cannot soundly be based upon specific forecasts of this type, or an average of them, but ought to take account of a considerable range of possibilities."'

The question now agitating many people is when the next down-

6 Economic Research and the Development of Economic Science and Public Policy (National Bureau, 1946), pp. 187-188. The italics are mine. 
turn in business will come, and how far it will take us. Men in high stations have made reassuring statements on these matters, and they are likely to multiply in coming months, especially if the downturn occurs. Unfortunately, the benevolent pronouncements rarely rest on firm knowledge. The paramount lesson of experience is that the only perfectly regular feature of business cycles is the recurrence of the phenomenon itself. For well over a century business cycles have run an unceasing round. They have persisted through vast economic and social changes; they have withstood countless experiments in industry, agriculture, banking, industrial relations, and public policy; they have confounded forecasters without number, belied repeated prophecies of a 'new era of prosperity,' and outlived repeated forebodings of 'chronic depression.' Men who wish to serve democracy faithfully must recognize that the roots of business cycles go deep in our economic organization, that the ability of government to control depressions adequately is not yet assured, that our power of forecasting is limited, and that true foresight requires policies for coping with numerous contingencies. 